\title{
Discussion on Talents Cultivation Goal and Curriculum Provision concerning the Major of Equestrian Sports and Management in Colleges and Universities \\ Peng DING
}

\author{
School of Physical Education, Wuhan Business University, Wuhan, 430056, China. \\ 949808799@qq.com
}

Keywords: Equestrian sports and management major, Cultivation goals, Curriculum provision.

\begin{abstract}
At present, there have been some problems concerning the talents cultivation goal and curriculum system of the major of equestrian sports and management in colleges and universities. The paper attempts to give an analysis of the talent cultivation orientation, cultivation goals and curriculum provision of the equestrian sports and management major in accordance with the status quos of the talent market of the Chinese equestrian industry, hoping to provide some ideas and strategies for the colleges and universities which engage in the cultivation of management talents of the equestrian industry, thus boosting the realization of the sustainable development of the management education of the equestrian sector.
\end{abstract}

\section{Introduction}

With the rapid development of the Chinese economy and the improvement of the life of the people, equestrianism and leisure riding as an important activity has attracted extensive attention among the people. Equestrianism and leisure riding have promoted the development of related industries, having a significant influence on the social development and the flourish of the sports undertakings.

In recent years, rapid development has been recorded concerning the Chinese equestrian clubs. Statistical data from the national equestrianism meeting show that the number of equestrian clubs, which was only 107 by the end of 2004, increased to 360 by the end of November 2010 with 300,000 registered members, and by the end of 2016 there have been 538 equestrian clubs with a certain scale. Furthermore, 2007 alone saw 60 equestrian clubs set up in China.

Equestrian sport has a long history in Wuhan. Wuhan Equestrian Club in Jinyin Lake boasts the only race course with international standard in central china, and it is also the only training base for equestrianism and horse racing of the General Administration of Sport of China and the Chinese Equestrian Association. Every week there is a horse racing day, and apart from that, special horse racing day also falls on May Day, the National Day, the Wuhan International Horsing Racing Festival and the annual final for horsing racing. 4 to 6 matches are held in every horse racing day. The holding of the frequent horse racing matches has not only promoted the influence of the city of Wuhan, but also boosted the development of the tourism as well as other related industries, bringing good economic and social benefits. Wuhan now is giving high priority to developing into the home of equestrianism in China, which will further enhance the development of equestrian industry of this city.

The growing equestrian industry has brought new challenges for the cultivation of sports talents. The existing talent cultivation mechanism fails to meet the requirements of the rapidly developing equestrian industry. The current situation of the Chinese equestrian industry is as follows: first, there is a lack of professional equestrian talents. According to the Chinese Equestrian Association, the demand of the professional equestrian talents is expected to exceed 100,000 by 2009. However, in a strict sense, there are only 200,000 people who are going for equestrianism at present. The lake of professional talents has impeded the development of the modern equestrian industry in China. Second, the equestrianism-related employees are not superior in education background, failing to accept professional education, and most employees are lack of professional theoretical knowledge with unsatisfactory innovative capacity. 
In 2008, Wuhan Business University (Wuhan Business Service College) signed agreement with Wuhan Jockey Club. As a result, the first equestrian college in China was established, with the aim to foster professional management talents for the equestrian industry.

The management and education of the equestrian industry is still feeling its way in China. The graduates fail to meet the rapid and constant development of the equestrian industry, and the talent cultivation model is still at an exploratory stage. As the Chinese equestrian industry develops fast, there is an urgent need for the management talents of this field. The colleges and universities are supposed to figure out those practical problems concerning what kind of management talents to cultivate and how the foster them.

\section{Analysis of Talent Requirements of the Chinese Equestrian Market}

Equestrian clubs are the main employment units for the students majoring in equestrian sports and management. By the end of 2016, there have been more than 500 equestrian clubs in China with most found in Beijing, Zhejiang, Shanghai, Guangzhou and Liaoning and other places. Those clubs are characterized with big scale and lack of employees.

It's found that the employees in the equestrian sector are relatively inferior in terms of education background with $82 \%$ graduated from primary schools, $13 \%$ from junior high schools and only $5 \%$ from colleges or universities. The employees haven't accepted professional study and lack theoretical knowledge with relatively inferior innovative capacity. These clubs are in need of high-quality and innovative talents with better capacity.

It's expected that 50,000 are needed for the existing 500 plus equestrian clubs in China in the next three years. Besides, another 120 equestrian clubs are predicted to increase from 2017 to 2019, which asks for another 30,000 employees. Therefore, there are 80,000 equestrian employees required in the next three years. However, considering the education situation regarding the equestrian industry management, it's clear that the students graduated from the major of equestrian management are unable to meet the requirements of the practical management of the equestrian industry. In a word, the employees in the equestrian industry fail to meet the equestrian industry in terms of quantity and quality.

\section{Talent Cultivation Goal of the Equestrian Sports and Management Major of Wuhan Business University}

Talent cultivation goal not only defines the essence of a kind of education, but also determines the reform and development direction of this education. Talent cultivation goal is the education direction of the colleges and universities, playing a vital role in the numerous factors of teaching. Besides, it is also the most basic evaluating indicator of the quality of the talents fostered by the schools. Therefore, the implement of talent cultivation goal directly concerns with the quality of the talents.

Wuhan Business University aims to develop itself into an application-oriented university featured with business-related curriculums and a talent cultivation base for the tertiary industry. Based on Wuhan and facing Hubei, the university tries to serve the modern service industry. The university seeks to foster professional business and technology talents with high quality for the local economic development especially the development in the service industry.

According to the school-running orientation, the general cultivation goal of the equestrian sports and management major is as follows: facing Hubei province and other places of China, serving for the tertiary industry, cultivating high quality applied and professional talents who develop morally, intellectually and physically, who embrace the basic lines of the Party and meet the requirements of the equestrian industry, who are equipped with good professional ethics and dedication, who master the basic knowledge and skills of the management concerning the equestrian industry, and who can serve as riding guides, stable keepers, reinsmen, and organizers of the equestrian matches.

To be specific, the students graduated from equestrian sports and management major are supposed to be able to ride, and have the practical ability concerning the breeding and nursing as well as disease prevention and treatment of the horses. Besides, those graduates are expected to be equipped with the 
ability of the normal management of the livery stable and the maintenance of the racing track. Furthermore, they should also have the ability to organize and manage the equestrian matches, to judge and plan a business equestrian match, and to design and implement the leisure equestrian activities.

The talent cultivation goal of the equestrian sports and management major is to foster high quality applied and professional talents under the background of the vigorous sports program. With the advantages of the equestrian sector in Wuhan, the talents are supposed to serve the regional economic development and adapt to the new and fashionable sports programs. The talent cultivation goal meets the requirements of the development of the equestrian industry.

\section{The Curriculum Provision of the Equestrian Sports and Management Major of Wuhan Business University}

Curriculum system is a system that arranges various course elements under the guidance of peculiar educational theories. Curriculum system is the carrier for the realization of the cultivation goal, and the key for the guarantee and improvement of the teaching quality.

The establishment of the curriculum system of the undergraduate education is to enhance the students' practical ability of the vocational skills and make them better serve their jobs in the future. When setting the curriculum, it's necessary to give high priority to the targeted posts or technology areas. During the practical cultivation, it's required to closely and organically integrate practice and theory, enabling the students to practice with the theoretical knowledge in mind. Besides, it's supposed to test the theoretical study of the students in the course of practice and improve the theoretical quality and practical ability of the students. High priority should first be given to the technological needs of the post in terms of the design of the specific content, and the courses are supposed to be practical and market-oriented while containing the theoretical elements. Some public courses are supposed to serve the lifelong education of a person, while the professional courses should focus on the market. In terms of practical operation, prior priority should be given to the improvement of the manipulative ability and the technical skills of the students.

Based on the basic talent cultivation goal and giving consideration to the needs of the talents, the university has made more efforts to the establishment and reform of the courses, trying to foster applied talents who are with excellent professional skills and who can gear to society.

(1) Clarifying the basic direction of the curriculum provision: Make greater efforts to establish the professional courses. Give priority to the instantaneity while improving the teaching management work. Try to integrate teaching with learning and incorporate the study of basic knowledge with the learning of professional skills. Pay attention to the establishment of the program concerning teaching quality so as to promote the development of the curriculum construction.

(2) Here are some tips for curriculum construction: Control the amount of class time. Focus on the professional core courses, and clarify the ratio of the practice courses and attach importance to the personalized development of the students. Implement the curriculum design that gives high priority to both basic theoretical knowledge and the cultivation of vocational ability. Optimize the teaching content, and Construct the curriculum system with features and with a reasonable structure.

(3) In terms of curriculum provision and time distribution, the practical teaching should be strengthened. In order to produce a better practical teaching effect, proper amount of class hours should be ensured. In general, the class hours of the practical teaching are supposed to occupy $40 \%$ of the total class hours, so that the students are able to receive targeted and systematic skill training. The class hours of the equestrian sports and management major have now occupied $52.3 \%$ of the total class hours, which shows that the practical teaching is ensured. Taking riding skill as an example, the riding theory and practice courses have been opened in the two semesters, altogether 144 class hours with the practical courses taking 120 class hours. During the daily teaching, the university would arrange the practical courses with consideration to the different personalities of the students. Thanks to the practical study, the students have broadened their horizons and improve their team working ability as well as their practical skills, making a solid foundation for their work in the future. 


\section{Suggestions}

(1) Continuing to Adjust and Improve the Talent Cultivation Model, and Focusing on the Long-term Cultivation Goal

In terms of curriculum provision and discipline construction, it's required to study not only the requirements of the PE major of the general colleges or universities, but also its development trend according to the specific features and practical requirements of this major, thus making the curriculum provision more scientific and reasonable and the talent cultivation scheme improved. More efforts should be made on the study of the requirements concerning the knowledge, ability and quality of different posts regarding the equestrian management talents. Talent cultivation scheme should be made according to the practical needs.

With the development of the equestrian industry, the need for related talents has increased, and it's likely that a growing number of universities will open this major. Meanwhile, more requirements will be imposed on the equestrian-related employees, so the colleges and universities are supposed to set a long-term talent cultivation goal.

(2) Reforming and Innovating the Curriculum System of the Equestrian Management Major

During the curriculum provision, it's necessary to change the ideas and foster the philosophy of putting people first and giving high priority to the students. Attention should be paid to both the job prospect and the long-term development of the students during the cultivation of the students. It's required to design some activity and practice in accordance with the work tasks of the equestrian sports and management major. Continuing to reform the curriculum system and construct the curriculum structure and system which is focused on the vocational ability. The cultivation scheme concerning the knowledge, ability and quality should be designed according to the ability requirements of the equestrianism-related posts. By so doing, it's expected to optimize the knowledge structure of the students, enhance the vocational quality of the students and help the students to better adapt to the work of the equestrian industry.

(3) Running a school by cooperating with the Equestrian Clubs and Related Companies

Combination of production and study and integration between schools and enterprises are the basic ways to cultivate applied high quality talents who can adapt to the requirements of the society. It's necessary for the universities to explore positively to strengthen cooperation with the related enterprises and enhance the talent cultivation model that combines production and study. The cooperation mechanism between the school and the enterprise is supposed to be established. Besides, the university is expected to give priority to the enterprises and be market-oriented. It's vital for the colleges and universities to establish the system concerning the running of a school with consideration to the specific features of themselves. Only by so doing, the students can become high quality talents who can adapt to the needs of the society.

The colleges and universities must pay attention to the current situation and development trend of the equestrian industry. It's necessary to strengthen communications with the equestrianism-related specialists and scholars, and listen to the advices and suggestions of them. The specialist consultation system can be established and the curriculum system can be constructed together with the experts of the equestrian clubs, thus making the graduates both practical and targeted.

\section{Acknowledgement}

This research was financially supported by the Provincial Teaching Research Project of the Colleges and Universities in Hubei Province(2016425).

\section{References}

[1] Ding Peng. Research on the Talent Cultivation of the Equestrian Management Major[D]. Wuhan: Hubei University, 2014.

[2] Li Xiang. Study on the Current Situation and Development Strategy of the Equestrian Clubs[D]. Tianjin: Tian University of Sport, 2013. 
[3] Xia Yunjian, Zeng Qingxuan. Research on the Talent cultivation of the Equestrian Management Major[J]. Journal of Wuhan Business University, 2015(3):17-19.

[4] Mang Lai. Development Trend of the Equestrian Industry of the Main Producing Areas in China[J]. XINJIANG XUMUYE,2016(9):42-49.

[5] Sun Zhuo. Research on the Optimization of Curriculum Provision of the Equestrianism Management Major[J]. Contemporary Sports Technology, 2015(10):76+78.

[6] Li Yaonan. Research on the Cooperation between Schools and Enterprises regarding Equestrian Management Major[J]. Journal of Wuhan Commercial Service College, 2011.25(4):71-73.

[7] Yu gang. Discussion on the Talent Cultivation Mechanism of production-learning Cooperation of the Equestrian Management Major[J]. Science \& Technology Information, 2011,(27):126-127.

[8] Wang Yong. Thoughts on the Development of Modern Equestrian Industry[J]. Gansu Animal and Veterinary Sciences,2016(21)43+48. 